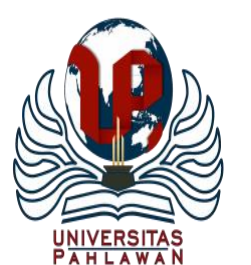

Jurnal Abdidas Volume 2 Nomor 4 Tahun 2021 Halaman 903-908

JURNAL ABDIDAS

http://abdidas.org/index.php/abdidas

\title{
Pelatihan dan Pendampingan Calon Mahasiswa Praktik Lapangan Persekolahan (PLP) tentang Aplikasi Google Classroom dalam Pembelajaran Era Pandemi Covid-19
}

\author{
Musdalifah Nurdin ${ }^{1}$, Andi Tanra Tellu ${ }^{2}$, Syech Zainal ${ }^{3 凶}$ \\ Universitas Tadulako, Indonesia ${ }^{1,2,3}$ \\ E-mail : Ifah_nurdin@yahoo.com ${ }^{1}$ tellu33@yahoo.com ${ }^{2}$ syechzainal67@gmail.com ${ }^{3}$
}

\begin{abstract}
Abstrak
Pelaksanaan pembelajaran saat ini mengharuskan pembelajaran daring/online serta melaksanakan social distancing dengan adanya wabah Covid-19. Kegiatan ini bertujuan meningkatkan wawasan dan kemampuan calon mahasiswa PLP Program Studi Pendidikan Biologi dalam penggunaan aplikasi Google Classroom untuk melaksanakan pembelajaran online Era Pandemi Covid-19. Kegiatan pelatihan dan pendampingan yang dilakukan memanfaatkan aplikasi Google Classroom. Materi yang diberikan pada kegiatan pelatihan dan pendampingan ini mulai dari pengenalan aplikasi dan software, membuat langkah-langkah pembelajaran, penyajian materi, membuat daftar hadir, serta evaluasi. Pelatihan ini dilakukan dalam dua tahap. Tahap pertama adalah sosialisasi dan pengenalan aplikasi software dan tahap kedua adalah simulasi penggunaan aplikasi dalam mengelola pembelajaran dan dilanjutkan dengan pendampingan. Hasil pelaksanaan kegiatan pelatihan dan pendampingan ini adalah meningkatnya wawasan, kemampuan calon mahasiswa PLP dalam menggunakan aplikasi Google Classroom baik pada android maupun menggunakan laptop serta menerapkannya pada proses pembelajaran di sekolah, baik dalam masa pandemi Covid-19 maupun situasi normal.
\end{abstract}

Kata kunci: kemampuan, mahasiswa PLP, google classroom, pembelajaran, Covid-19

\section{Abstract}

The current implementation of learning requires online learning as well as implementing social distancing due to the Covid-19 outbreak. This activity aims to increase the insight and ability of prospective PLP students of the Biology Education Study Program in using the Google Classroom application to carry out online learning in the Covid-19 Pandemic Era. The training and mentoring activities are carried out using the Google Classroom application. The material provided in this training and mentoring activity starts from introducing applications and software, making learning steps, presenting material, making attendance lists, and evaluating. This training is carried out in two stages. The first stage is the socialization and introduction of software applications and the second stage is a simulation of the use of applications in managing learning and continued with mentoring. The result of the implementation of this training and mentoring activity is an increase in insight, the ability of prospective PLP students to use the Google Classroom application both on Android and using a laptop and apply it to the learning process at school, both during the Covid-19 pandemic and normal situations.

Keywords: ability, student PLP, google classroom, learning, Covid-19

Copyright (c) 2021 Musdalifah Nurdin, Andi Tanra Tellu, Syech Zainal

$\triangle$ Corresponding author

Address : Program Studi Pendidikan Biologi-FKIP

Email : syechzainal67@gmail.com

ISSN 2721- 9224 (Media Cetak)

DOI : https://doi.org/10.31004/abdidas.v2i4.392

ISSN 2721- 9216 (Media Online) 
904 Pelatihan dan Pendampingan Calon Mahasiswa Praktik Lapangan Persekolahan (PLP) tentang Aplikasi Google Classroom dalam Pembelajaran Era Pandemi Covid-19- Musdalifah Nurdin, Andi Tanra Tellu, Syech Zainal

DOI: https://doi.org/10.31004/abdidas.v2i4.392

\section{PENDAHULUAN}

Pemanfaatan teknologi di bidang pendidikan memberikan peluang yang besar kepada calon pendidik dan pendidik dalam mengembangkan model pembelajaran yang menarik dan interaktif, khususnya dalam proses pembelajaran. Perkembangan teknologi tentunya harus dibarengi dengan peningkatan kemampuan sumber daya manusia, termasuk guru atau pendidik sebagai penentu kualitas pendidikan. Berbagai hasil penelitian menunjukkan bahwa pemanfaatan komputer dapat berpengaruh terhadap prestasi belajar siswa (Prasmono, 2011).

Perkembangan teknologi informasi dan komunikasi di era industri 4.0 memiliki pengaruh besar terhadap proses pembelajaran. Menurut Keengwe \& Georgina (2012) dalam penelitiannya menyatakan bahwa perkembangan teknologi memberikan perubahan terhadap proses pengajaran dan pembelajaran. Pengunaan internet yang semakin luas dan canggih sebagai sarana untuk mempermudah pembelajaran. Pembelajaran berbasis daring (online) dibutuhkan sebagai sarana atau alat untuk mendukung proses pembelajaran saat ini. Salah satu media teknologi yang sering digunakan saat ini adalah telepon genggam/ ponsel dengan berbagai perangkat lunaknya. Hasil penelitian Gheytasi, et al. (2015) menunjukkan bahwa siswa yang banyak berinteraksi dengan aplikasi di telepon genggam lebih mudah memahami isi teks bacaan. Berbagai macam media pembelajaran yang ada namun belum digunakan oleh guru secara maksimal. Salah satunya adalah penggunaan media aplikasi Google Classroom dapat dimanfaatkan sebagai media pembelajaran untuk membantu meningkatkan hasil belajar siswa. Desain dari Google Classroom sudah tidak asing lagi bagi siswa karena mereka sudah menggunakan beberapa produk dari google via akun Google Apps (Izenstark dan Leahy, 2015).

Permasalahan di dalam pendidikan merupakan prioritas utama yang harus dipecahkan, salah satunya adalah masalah kualitas pendidikan. Kualitas pendidikan saat ini tengah mengalami tantangan sebagai dampak mewabahnya virus Covid-19. Virus ini menjadi pandemik global yang penyebarannya begitu menghawatirkan. Akibatnya pemerintah harus bekerja sama untuk menekan laju penyebaran virus Covid-19 dengan mengeluarkan kebijakan agar seluruh warga masyarakat untuk melakukan social distancing (Mendikbud, 2020).

Pelaksanaan praktik Pengenalan Lapangan Persekolahan (PLP) dijadwalkan dan dilaksanakan di sekolah sebanyak dua kali dalam setahun oleh Unit Pengembangan Sumberdaya Pembelajaran (UPSP) FKIP Universitas Tadulako. Calon mahasiswa PLP khususnya mahasiswa Program Studi Pendidikan Biologi merupakan agen yang dapat melakukan praktik mengajar sekaligus membantu guru-guru dalam proses pelaksanaan pembelajaran di sekolah. Oleh karena itu, sebelum pelaksanaan PLP dilakukan, sebaiknya mahasiswa dibekali berbagai kemampuan dalam menggunakan aplikasi platform pembelajaran yang ditawarkan oleh Kementerian Pendidikan, Kebudayaan, Riset dan Teknologi. Sejak Covid-19 mewabah hingga nanti telah kembali situasi normal. Salah satu platform pembelajaran online 
905 Pelatihan dan Pendampingan Calon Mahasiswa Praktik Lapangan Persekolahan (PLP) tentang Aplikasi Google Classroom dalam Pembelajaran Era Pandemi Covid-19- Musdalifah Nurdin, Andi Tanra Tellu, Syech Zainal

DOI: https://doi.org/10.31004/abdidas.v2i4.392

yang dapat memudahkan guru dalam melaksanakan pembelajaran di kelas adalah aplikasi Google Classroom.

Penggunaan Google Classroom sebagai salah satu alternatif pembelajaran online yang ditawarkan dalam mengelola pembelajaran. Aplikasi Google Classroom dapat mempermudah guru dalam mengelola pembelajaran dan menyampaikan informasi secara cepat dan akurat kepada siswa (Hardiyana, 2015). Google Classroom didesain untuk empat pengguna yaitu pengajar, siswa, wali dan administrator. Kelebihan aplikasi Google Classroom dibandingkan dengan aplikasi lain yaitu aplikasi Google Classroom dapat digunakan untuk membuat dan mengelola kelas, tugas, nilai serta memberikan masukan secara langsung. Siswa dapat memantau materi dan tugas kelas, berbagi materi dan berinteraksi dalam kelas atau melalui email, mengirim tugas dan mendapatkan masukan nilai secara langsung.

Berdasarkan hasil wawancara dengan beberapa mahasiswa yang akan melaksanakan PLP, umumnya mereka belum memahami penggunaan Google Classroom. Untuk mengatasi kondisi tersebut, mahasiswa perlu dibekali dengan pengetahuan dan keterampilan dalam menggunakan media pembelajaran Google Classroom.

Berdasarkan fenomena tersebut di atas, mendorong pengabdi dan menganggap sangat perlu untuk melakukan kegiatan yang bertujuan membekali sejak dini calon mahasiswa PLP Program Studi Pendidikan Biologi berupa pelatihan dan pendampingan penggunaan aplikasi
Google Classroom dalam pembelajaran di era pandemi Covid-19 sehingga wawasan dan kemampuan mahasiswa dalam melaksanakan pembelajaran online di sekolah meningkat.

\section{METODE}

Kegiatan ini dilakukan dengan menggunakan pendekatan "andragogi", yaitu kegiatan berbasis pembelajaran orang dewasa, yang lebih menitikberatkan pada pelibatan peserta pelatihan lebih aktif.

Kegiatan pelatihan ini dilaksanakan di Program Studi Pendidikan Biologi FKIP UNTAD dengan tetap mematuhi protokol kesehatan. Dilaksanakan dalam dua sesi bagian dan setiap sesi berjumlah 15 orang mahasiswa. Menyesuaikan dengan pelaksanaan PLP dalam lingkungan FKIP Universitas Tadulako. Secara umum pelaksanakan kegiatan pengabdian ini dilakukan dalam tiga tahapan.

Tahap pertama; melakukan sosialisasi dan identifikasi terkait pengetahuan dan kemampuan Calon Mahasiswa PLP tentang aplikasi dan penggunaan Google Classroom.

Tahap Kedua; penyampaian materi tentang pengenalan software dan keunggulannya sebagai salah satu platform pembelajaran online yang direkomendasikan.

Tahap Ketiga; adalah simulasi penggunaan dan aplikatif software Google Classroom dalam mengelola hingga melaksanakan evaluasi pembelajaran. 
906 Pelatihan dan Pendampingan Calon Mahasiswa Praktik Lapangan Persekolahan (PLP) tentang Aplikasi Google Classroom dalam Pembelajaran Era Pandemi Covid-19- Musdalifah Nurdin, Andi Tanra Tellu, Syech Zainal

DOI: https://doi.org/10.31004/abdidas.v2i4.392

\section{HASIL DAN PEMBAHASAN}

Kegiatan awal dari pelaksanaan pengabdian ini pada bulan April 2021. Kegiatan ini diawali beberapa persiapan antara lain observasi dan review kendala mahasiswa di lapangan saat melaksanakan PLP, khususnya calon mahasiswa PLP Prodi Pendidikan Biologi dalam melaksanakan pembelajaran online menggunakan Google Classroom, pembentukan tim pengabdi, menentukan tema dan judul, serta pembagian tugas tim.

Akibat semakin melonjaknya angka penularan Covid-19 di daerah kami, maka kami tim pengabdi berinisiasi untuk melaksanakan pelatihan sesi 1 pada tanggal 27 Juli 2021 dengan tahapan berikut:

1. Penyampaian dan pemaparan materi oleh narasumber yang dalam kesempatan itu disampaikan oleh Bapak Syech Zainal yang juga merupakan anggota Tim pengabdi yang menyampaikan tentang pengenalan software Google Classroom dan keunggulannya sebagai salah satu platform pembelajaran online yang direkomendasikan. Ketua pengabdi (Ibu Musdalifah Nurdin) dan anggota (Bapak Andi Tanra Tellu) turut andil dan berkontribusi besar untuk membantu dalam memberikan penjelasanpenjelasan kepada peserta pelatihan.

2. Melakukan simulasi sekaligus praktik aplikatif penggunaan software aplikasi Google Classroom bawaan akun Gmail dalam mengelola pembelajaran (membuat langkah-langkah pembelajaran, penyajian materi, membuat daftar hadir, evaluasi) dan mencetak hasil penilaian dari aplikasi Google Classroom dalam bentuk Excel maupun bentuk lainnya sesuai kebutuhan.

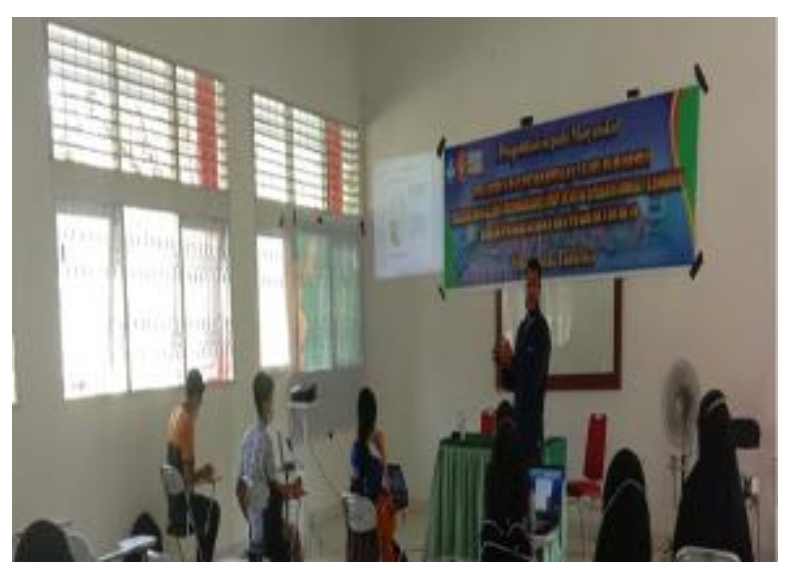

Gambar 1. Pemaparan Materi Sesi 1

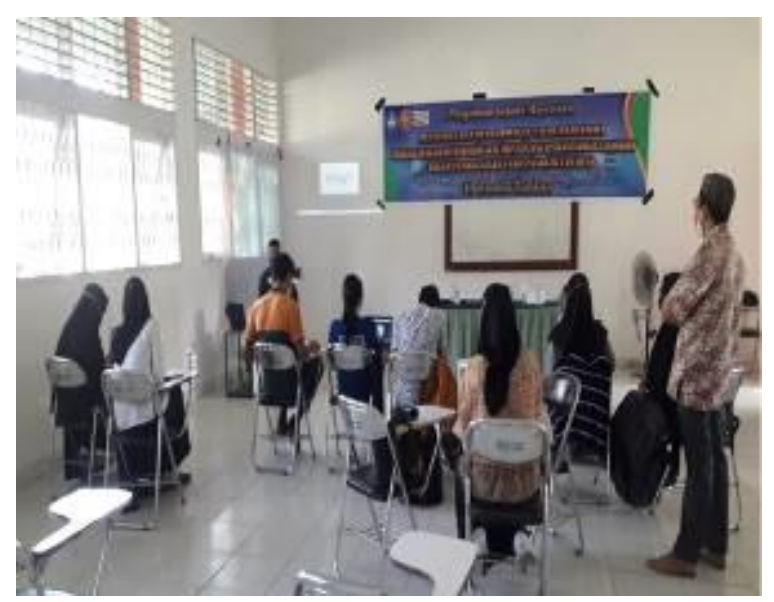

Gambar 2. Simulasi Aplikasi Sesi 1

Pelaksanaan pelatihan sesi 2 dilaksanakan pada tanggal 28 Juli 2021 dengan tahapan yang sama dengan pada sesi 1 . 
907 Pelatihan dan Pendampingan Calon Mahasiswa Praktik Lapangan Persekolahan (PLP) tentang Aplikasi Google Classroom dalam Pembelajaran Era Pandemi Covid-19- Musdalifah Nurdin, Andi Tanra Tellu, Syech Zainal

DOI: https://doi.org/10.31004/abdidas.v2i4.392

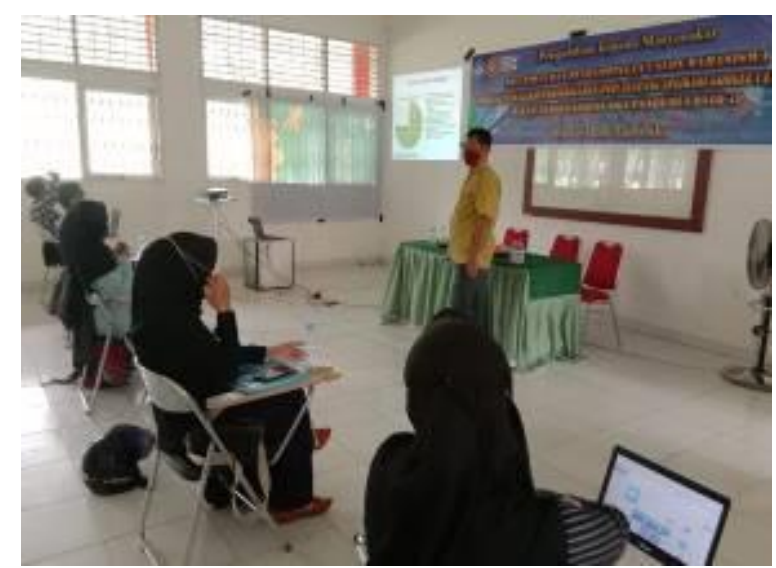

Gambar 3. Pemaparan Materi Sesi 2

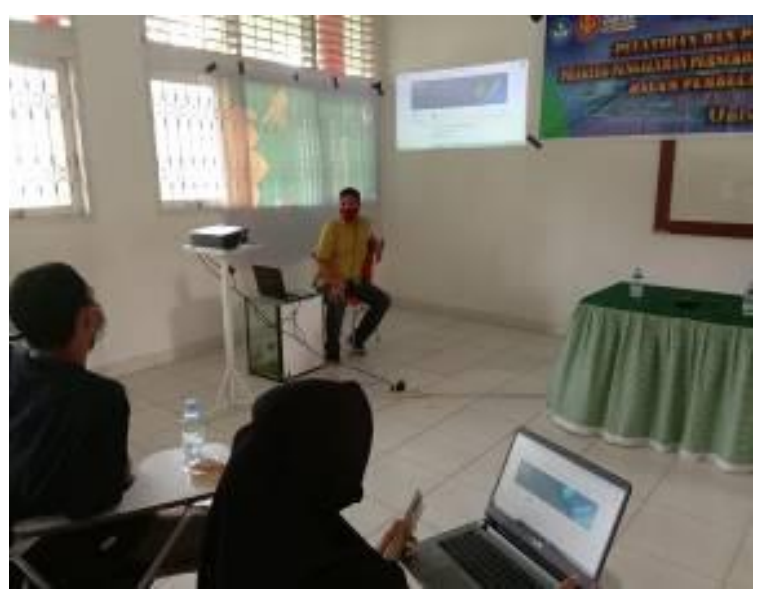

Gambar 4. Simulasi Aplikasi Sesi 2

Hasil survei yang dilakukan tim pengabdi berupa penyebaran angket kepada seluruh peserta pelatihan setelah selesai pelatihan melalui Google Form, diperoleh hasil bahwa lebih dari 92,5\% peserta menyatakan senang menggunakan Google Classroom dan $88,4 \%$ menyatakan setuju dan antusias agar pembelajaran online dengan menggunakan Google Classroom tetap dipertahankan atau digunakan meskipun pandemi telah berakhir. Hasil observasi terhadap kemampuan mahasiswa mengunaakan Google Classroom selama pelatihan dan evaluasi akhir kegiatan tahap pertama ini, mengalami peningkatan, meskipun masih diperlukan penguatan dalam bentuk pendampingan.

Hasil-hasil tersebut sejalan dengan temuan Suhery, et al. (2020) yang melaporkan hasil pengabdian masyarakat bahwa peserta sangat berminat dengan pelatihan ini. Penambahan pengetahuan bagi peserta tentang penggunaan aplikasi Zoom Meeting dan Google Classroom yang baik dan benar, serta cepat dengan menerapkan secara langsung.

Kegiatan ini tidak hanya sebatas atau berakhir pada pelatihan saja, namun tim pengabdi juga akan tetap melakukan pendampingan terkait penggunaan Google Classroom kepada mahasiswa yang mengalami kendala dalam mengelola pembelajaran di sekolah tempat mereka melaksanakan praktik lapangan baik secara tatap muka maupun online.

\section{SIMPULAN}

Berdasarkan hasil evaluasi capaian pelaksanaan pengabdian masyarakat dapat ditarik kesimpulan bahwa hasil kegiatan pelatihan dan pendampingan ini adalah meningkatnya wawasan dan kemampuan calon mahasiswa PLP dalam menggunakan aplikasi Google Classroom dalam mengelola pembelajaran. Perolehan hasil persentase angket Google Form bahwa lebih dari $92,5 \%$ peserta menyatakan sangat senang menggunakan Google Classroom dan 88,4\% menyatakan setuju dan antusias agar pembelajaran online dengan menggunakan Google Classroom tetap dipertahankan atau digunakan, meskipun pandemi telah berakhir. 
908 Pelatihan dan Pendampingan Calon Mahasiswa Praktik Lapangan Persekolahan (PLP) tentang Aplikasi Google Classroom dalam Pembelajaran Era Pandemi Covid-19- Musdalifah Nurdin, Andi Tanra Tellu, Syech Zainal

DOI: https://doi.org/10.31004/abdidas.v2i4.392

\section{UCAPAN TERIMA KASIH}

Ucapan terima kasih kami sampaikan kepada pimpinan Universitas, Lembaga Penelitian dan Pengabdian Masyarakat serta Dekan FKIP Universitas Tadulako yang telah mengalokasikan dana BLU melalui DIPA Fakultas (FKIP) tahun anggaran 2021 sehingga pengabdian ini dapat terlaksana.

\section{DAFTAR PUSTAKA}

Gheytasi, M., Azizifar, A., \& Gowhary, H. (2015). The Effect of Smartphone on the Reading Comprehension Proficiency of Iranian EFL Learners. Procedia - Social and Behavioral Sciences, 199, 225-230. https://doi.org/10.1016/J.SBSPRO.2015.07.51 $\underline{0}$

Hardiyana, A. (2015). Implementasi Google Classroom sebagai Alternatif dalam Meningkatkan Mutu Pembelajaran di Sekolah. Karya Tulis Ilmiah, Cirebon : SMA Negeri 1 Losari.

Izenstark, Amanda and Katie L. L. (2015). "Google Classroom for Librarians : Features and Opportunities." Library Hi Tech News 32 (9):1-3. https://doi.org/10.1108/LHTN-052015-0039

Keengwe, J., \& Georgina, D. (2012). The digital course training workshop for online learning and teaching. Education and Information Technologies, 17(4), 365- 379. https://doi.org/10.1007/s10639-011-9164-x

Prasmono, A. (2011). Pengaruh Penggunaan Media Pembelajaran Komputer Multimedia Dan Digital Video Disc Terhadap Prestasi Belajar Listening Ditinjau Dari Motivasi Belajar Siswa Sekolah Menengah Pertama Di Kabupaten Wonogiri. Digital Library UPT. Perpustakaan Universitas Sebelas Maret. Solo.

Pusdiklat Pegawai Kementerian Pendidikan dan Kebudayaan, (2020). Surat Edaran Mendikbud Nomor 4 Tahun 2020 Tanggal 24
Maret tentang Pelaksanaan Kebijakan Pendidikan dalam Masa Darurat Penyebaran Corona Virus Disease (Covid19).https://pusdiklat.kemdikbud.go.id/suratedaran-mendikbud-no-4-tahun-2020-tentangpelaksanaan-kebijakanpendidikan-dalammasa-darurat penyebaran-corona-virusdisease-covid-1-9/

Suhery; Putra T. J \& Jasmalinda. (2020). Sosialisasi Penggunaan Aplikasi Zoom Meeting dan Google classroom Pada Guru Di Sdn 17 Mata Air Padang Selatan. Jurnal Inovasi Penelitian. Vol.1 (3): 129-132. 